\title{
Menakar Kehalalan Mall
}

\author{
Oleh: Andika Saputra, S.T., M.Sc \\ Dosen Prodi Arsitektur Universitas Muhammadiyah Surakarta \\ Pusat Studi Arsitektur Islam Universitas Muhammadiyah Surakarta
}

Keinginan untuk menulis artikel ini bermula setelah saya membaca sebuah berita yang dirilis oleh portal berita online www.depokpos.com bertajuk "The Park Sawangan, Mall Dengan Konsep Hypermart Halal Pertama di Depok". Tulisan ini tidak saya tujukan untuk menyoroti secara khusus The Sawangan Mall, tetapi hendak menempatkannya sebagai bagian dari fenomena penyematan status Halal atau Islami pada ruang ekonomi kontemporer yang lazim disebut Mall atau Plaza oleh masyarakat luas. Kehadiran fenomena ini tidak dapat dilepaskan dari tumbuh suburnya gairah keagamaan umat Islam di lingkungan urban yang di satu sisi belum dapat sepenuhnya meninggalkan gaya hidup kontemporer yang tidak bersumberkan dari Islam dan tradisi Islam, sedangkan di sisi yang lain memiliki semangat yang tinggi untuk mengamalkan Islam dalam kehidupan sehari-hari. Tarik-menarik dua kutub yang berbeda arah di dalam diri masyarakat Muslim urban, salah satunya menumbuhkan kebutuhan kehadiran Mall sebagai ruang ekonomi kontemprer yang sesuai dengan identitas diri sebagai umat Islam.

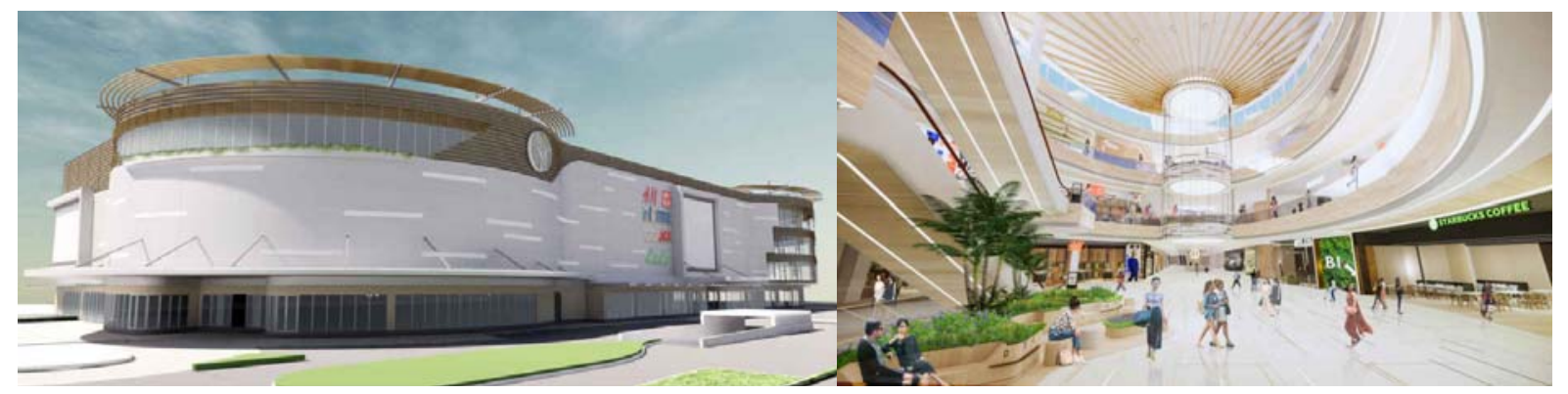

Gambar 1: Tampak depan (kiri) dan atrium (kanan) The Sawangan Mall yang merupakan Mall dengan konsep Hypermart Halal pertama di Depok.

Sumber: www. depokpos.com, 2019.

Tulisan ini yang saya beri judul Menakar Kehalalan Mall terdiri dari tiga bagian. Bagian pertama menyoroti perkembangan ruang ekonomi secara evolutif dari pasar tradisional hingga Mall. Bagian kedua memaparkan ciri khas Mall dan perbedaannya dengan ruang ekonomi pada masa-masa sebelumnya. Dan pada bagian ketiga tulisan ini memuat gugatan-gugatan saya terhadap penyematan istilah Halal maupun Islami pada Mall. 


\section{A. Evolusi Ruang Ekonomi}

J ika kita menengok kepada tiga generasi ke belakang, dalam kehidupan ekonominya hanya mengenal istilah pasar yang diperuntukkan sebagai ruang untuk memenuhi kebutuhan sehari-hari melalui kegiatan jual-beli. Pasar pada awalnya tidak merujuk pada kualitas ruang tertentu yang ditujukan untuk mewadahi kegiatan ekonomi, tetapi merujuk pada aktivitas jual-beli yang secara kultural berlangsung pada hari dan jam tertentu di tempat yang tidak secara khusus ditujukan dan dipersiapkan untuk mewadahi kegiatan ekonomi, seperti tanah lapang di area permukiman maupun di sekitar tempat peribadatan. Seiring berjalannya waktu, istilah pasar merujuk pada suatu ruang yang diperuntukkan khusus untuk mewadahi kegiatan ekonomi para pedagang dan pembeli dalam lingkup lokal, yang kini kita menyebutnya dengan istilah pasar tradisional. Istilah 'tradisional' yang disematkan pada pasar bermakna ruang lingkup pelayanan pasar, barang yang diperjualbelikan, praktik jual-beli yang merupakan bagian dari adat masyarakat setempat, dan kualitas arsitektur yang dibangun dengan bahan, teknik, dan sumber daya manusia setempat.

Pasar tradisional yang dinilai usang dari segi kualitas arsitekturnya karena telah tertinggal jauh dari kemajuan zaman, perubahan lingkungan pasar yang dahulu merupakan wilayah pedesaan kini telah menjadi area urban, serta kondisi lingkungan pasar tradisional yang kotor berserakan sampah, bau tidak sedap, genangan air di lantai, hingga kondisi bangunan yang mengalami kerusakan di banyak bagiannya, mulai digantikan dengan pasar modern yang dari aspek arsitekturalnya menerapkan bahan dan teknik pembangunan modern untuk memperpanjang durasi masa pakai ruang, mewujudkan kondisi ruang yang bersih dan higienis sebagaimana tuntutan kehidupan urban, dan tentu saja untuk merubah wajah kota agar konteks dengan kemajuan zaman.

Tidak terdapat perbedaan berarti antara pasar tradisional dan pasar modern selain kualitas arsitekturnya yang menggunakan bahan dan teknik pembangunan modern. Tata ruang pasar tidak berubah dengan jalur sirkulasi sempit sebatas dapat dilalui dua orang yang diapit kios dagangan di samping kiri dan kanan, sehingga perilaku berdesak-desakan antar pembeli tidak dapat hindari pada waktu-waktu tertentu, seperti pada pagi hari apalagi pada saat menjelang perayaan hari raya. Orientasi kegiatan ekonomi yang berlangsung di pasar modern pun tidak berubah, yakni sebatas untuk melangsungkan kegiatan jual-beli untuk memenuhi kebutuhan hidup sehari-hari, sehingga durasi kegiatan ekonomi yang berlangsung di pasar tradisional maupun modern terbilang cepat karena setelah kebutuhan terpenuhi, pembeli akan sesegera mungkin meninggalkan ruang pasar. 
Terlebih pada pasar tradisional dengan kualitas lingkungan yang rendah, secara psikologis mendorong pembeli untuk semakin mempersingkat waktu kegiatannya di dalam pasar dengan meningkatkan ritme kegiatan yang sudah pasti menyebabkan perilaku saling dorong dan berdesak-desakan di jalur sirkulasi pasar yang sempit tidak dapat dihindari.

Zaman yang terus bergerak memasuki periode modern mendesak kota untuk berkembang yang ditandai dengan kehadiran ruang ekonomi baru, yakni pusat perbelanjaan modern. Makna kata 'pusat perbelanjaan' meliputi (1) barang dagangan yang lebih beragam sebagai konsekuensi terjalinnya jaringan ekonomi global, sehingga barang yang diproduksi di lain benua dapat dipasarkan di Indonesia; (2) manajemen berasaskan ilmu pengetahuan modern untuk pengelolaan ruang ekonomi lebih efisien dan efektif; (3) dimensi ruang yang lebih luas untuk mewadahi pengguna dalam jumlah yang lebih banyak; dan (4) kualitas arsitektur yang modern dengan dimensi jalur sirkulasi yang lebar serta pencahayaan dan penghawaan ruang yang terkontrol melalui penerapan teknologi modern untuk memberikan kenyamanan kepada pengunjung melakukan kegiatan ekonomi di pusat perbelanjaan modern. Keempat poin tersebut yang merupakan ciri khas pusat perbelanjaan modern ditujukan oleh pemilik ruang untuk mendapatkan keuntungan berlipat dengan cara memperluas area lingkup pelayanan hingga skala kota yang membedakannya dengan pasar yang bersifat lokal, dan meningkatkan durasi kegiatan ekonomi yang dilakukan pembeli di pusat perbelanjaan modern.

Perbedaan orientasi yang menentukan durasi kegiatan ekonomi di pusat perbelanjaan modern dan pasar disebabkan perberdaan landasan kegiatan ekonomi yang berasaskan utilitarian menjadi hedonistik khas gaya hidup konsumtif masyarakat urban. Tidak sebagaimana terjadi di pasar, orientasi pengunjung berkegiatan ekonomi di pusat perbelanjaan modern bukan saja sekedar membeli barang yang dibutuhkan, tetapi juga memilih identitas diri melalui merk dan citra barang yang diperjualbelikan. Sehingga meningkatnya durasi kegiatan ekonomi di pusat perbelanjaan modern dikarenakan pembeli tidak memilih dan membeli barang sesuai fungsi yang memungkinkan kegiatan ekonomi dapat dituntaskan dalam waktu cepat, tetapi berdasarkan imajinya terhadap diri yang hendak ditampilkan dengan mengenakan atau memiliki suatu barang. Pembayangan secara psikologis itulah yang menyebabkan meningkatnya durasi kegiatan ekonomi di pusat perbelanjaan modern karena memilih identitas yang hendak dipilih dari beragam produk yang diperjualbelikan dengan jumlah yang begitu banyak memberikan kesenangan psikologis bagi pembeli. 
Dalam perkembangan mutakhirnya, pusat perbelanjaan modern telah sampai pada evolusi yang disebut Mall. Berbeda dengan tujuan pusat perbelanjaan modern untuk membentuk gaya hidup konsumtif masyarakat urban melalui merk dan citra barang yang diperjualbelikan, Mall bertujuan menjadikan berkunjung dan berkegiatan ekonomi di Mall itu sendiri sebagai gaya hidup konsumtif masyarakat urban. Untuk mencapai tujuannya, Mall tidak dapat sepenuhnya mengandalkan strategi pembayangan psikologis bagi pembeli untuk meningkatkan durasi kegiatan ekonomi, karena mengandalkan barang yang diperjualbelikan yang merupakan unsur 'Iuaran' dari Mall. Dibutuhkan intensitas kunjungan yang tinggi dan berkelanjutan serta durasi kegiatan ekonomi yang panjang untuk mencapai tujuan Mall, sehingga selain mengandalkan unsur 'luaran', Mall juga harus mengandalkan unsur 'dalaman' sebagai wadah kegiatan ekonomi, meliputi bentukan arsitektur, fasilitas, suasana ruang, dan orientasi ruang.

Perbedaan intensitas kunjungan antara pusat perbelanjaan modern dan Mall dengan mudah dapat diamati. Pada umumnya masyarakat berkunjung ke pusat perbelanjaan modern pada hari libur, yakni rata-rata sekali dalam sepekan atau bahkan hanya sekali atau dua kali dalam sebulan. Dibandingkan dengan Mall, intensitas masyarakat mengunjungi Mall dapat terbilang setiap hari karena Mall bukan hanya ruang ekonomi, tetapi ruang gaya hidup urban yang mewadahi kegiatan jual-beli, bekerja, berkumpul, berolahraga, hingga rekreasi, sehingga menjadikan Mall sebagai ruang rutin yang dikunjungi oleh masyarakat dalam rangkaian kegiatannya sehari-hari.

Perkembangan ruang ekonomi dari pasar tradisional menjadi pasar modern, dan mengalami patahan pada kehadiran pusat perbelanjaan modern yang berevolusi menjadi Mall, secara filosofis disebabkan terjadinya perubahan cara pandang (worldview) terkait tujuan hidup manusia, tujuan kegiatan ekonomi, dan kedudukan kegiatan ekonomi untuk mencapai tujuan hidupnya. Kegiatan ekonomi di pasar tradisional berorientasi ekonomisosial yang bermakna dua hal. Pertama, keberlangsungan kegiatan ekonomi bergantung pada modal sosial dan jejaring sosial yang mengikat pedagang dan pembeli. Oleh karena itu terjadinya transaksi jual-beli di pasar tradisional tidak dapat dilepaskan dari pengaruh kedekatan personal antara pedagang dan pembeli. Kedua, kegiatan ekonomi yang berlangsung di pasar tradisional, selain mendapatkan keuntungan ekonomi, diprioritaskan untuk memperkuat ikatan sosial yang telah terjalin maupun menjalin ikatan sosial yang baru melalui obrolan ringan tatap muka dan mekanisme tawar menawar dalam transaksi jual-beli untuk mendapatkan kesepakatan harga antara pedagang dan pembeli. 
Pada pasar modern, orientasi ekonomi-sosial tetap berlangsung, walaupun semakin melemah sebagai akibat perluasan pelayanan pasar yang tidak saja meliputi modal sosial di sekitar lingkungan pasar, tetapi juga kalangan masyarakat dari lain wilayah hingga kalangan wisatawan dari luar wilayah. Melemahnya orientasi sosial dalam kegiatan ekonomi di pasar modern terlihat dari perlakuan dan harga barang yang berbeda oleh pedagang kepada pihak pembeli yang asing baginya karena tidak berasal dari lingkungan sosial yang sama, sehingga tidak terjalin ikatan sosial antara kedua belah pihak. Identifikasi terhadap pembeli oleh pedagang yang mendasari perbedaan perilau jual-beli mengandalkan pengalaman sehari-hari dan atribut fisik, yakni jika tidak dikenalinya dalam kehidupan sehari-hari dan memiliki ciri fisik serta tutur bahasa yang berbeda, maka akan dinilai sebagai pihak asing oleh pedagang.

Orientasi ekonomi-sosial tidak lagi berlaku pada pusat perbelanjaan modern dan Mall yang berorientasi mendapatkan keuntungan ekonomi sebanyak-banyaknya dari modal seminimal mungkin. Dengan orientasi ekonomi-kapitalistik yang menihilkan keuntungan sosial dalam transaksi jual-beli, kegiatan ekonomi yang berlangsung di pusat perbelanjaan modern dan Mall tidak mensyaratkan ikatan sosial antara pihak pedagang dan pembeli, begitupula antara pihak pemilik Mall dengan pedagang sebagai penyewa gerai. Seluruh pihak yang terlibat dalam kegiatan ekonomi berstatus anonim yang menjadikan penentuan harga-pasti (fixed price) dapat dilakukan dan mekanisme tawar menawar dapat ditiadakan untuk menjamin keuntungan ekonomi yang didapatkan.

\section{B. Ciri Khas Mall}

Mall yang merupakan evolusi mutakhir dari pusat perbelanjaan modern memiliki empat ciri khas yang membedakan Mall dengan ruang ekonomi selainnya. Keempat ciri khas Mall yang akan dibahas di bawah dibentuk berdasarkan (1) tujuan kehadiran Mall untuk menjadikan berkunjung dan berkegiatan ekonomi di Mall sebagai gaya hidup konsumtif masyarakat urban; dan (2) strategi mencapai tujuan Mall dengan cara meningkatkan secara berkelanjutan intensitas kunjungan dan memperpanjang durasi kegiatan ekonomi dengan menjadikan Mall sebagai ruang tujuan rutin dalam rangkaian kegiatan sehari-hari masyarakat.

Ciri khas pertama, Mall menerapkan bentukan arsitektur yang rekreatif, yakni menyenangkap secara visual dan emosional untuk mempengaruhi psikologis masyarakat berupa dorongan berkunjung ke Mall disebabkan rasa penasaran terhadap apa yang terdapat di dalam Mall berdasarkan keterpikatan dan kekaguman dirinya terhadap 
bentukan arsitektur Mall. Secara fungsional ciri khas pertama ini dibutuhkan untuk meningkatkan secara cepat jumlah kunjungan masyarakat ke Mall pada masa-masa awal Mall beroperasi.

Ciri khas kedua, Mall dilengkapi fasilitas pendukung yang bersifat hiburan (entertainment) seperti (1) arena bermain anak untuk meningkatkan intensitas kunjungan ke Mall secara berkelanjutan dengan memanfaatkan orientasi bermain anak serta untuk memperpanjang durasi kegiatan ekonomi dengan memberikan rasa tenang secara psikologis bagi orangtua yang mengajak anak ke Mall; dan (2) event-event hiburan seperti live musik, penyelenggaraan lomba, dan perayaan festival untuk mendorong masyarakat mengunjungi Mall sebagai agenda dari rangkaian kegiatannya sehari-hari.

Ciri khas ketiga, Mall memiliki nuansa ruang yang menggunggah kondisi psikologis masyarakat secara emosional melalui pemilihan lokasi dan perancangan tata ruang Mall. Ditinjau dari aspek lokasinya, pembangunan Mall mempertimbangkan potensi lingkungan sekitar untuk dimanfaatkan sebagai daya tarik memikat masyarakat berkunjung dan berkegiatan di Mall, seperti lokasi yang berbedakatan dengan pantai maupun memiliki arah pandang langsung ke area pantai. Dengan nuansa ruang Mall yang dibentuk oleh kehadiran pantai didekatnya, Mall memiliki daya tarik yang kuat untuk mempengaruhi masyarakat berkunjung dan berkegiatan di Mall sambil bermain di pantai atau menikmati matahari terbenam dari area Mall yang berbatasan dengan pantai. Sementara itu ditinjau dari aspek tata ruangnya, Mall turut mempertimbangkan pembentukan iklim mikro yang baik melalui ruang terbuka hijau di area depan Mall atau di area tengah Mall yang membentuk inner courtyard untuk memberikan kenyamanan bagi masyarakat berkegiatan dalam durasi yang panjang sekaligus meningkatkan intensitas kunjungan masyarakat ke Mall dengan memfungsikannya sebagai ruang komunal.

Ciri khas keempat, Mall memiliki orientasi ke arah dalam yang diwujudkan secara arsitektural melalui dua cara, yakni (1) meminimalkan bukaan ke arah ruang luar dengan bentukan arsitektural yang masif. Unsur bukaan yang bersifat fungsional sebagai penghubung ruang luar dengan ruang dalam Mall terbatas pada pintu sebagai jalur sirkulasi keluar dan memasuki bangunan. Sementara itu bidang kaca yang pada umumnya memenuhi wajah depan bangunan Mall merupakan unsur estetika semata untuk memberikan keindahan pada bentukan arsitektur Mall, dan tidak berfungsi secara fungsional untuk sirkulasi cahaya maupun udara; dan (2) menjadikan atrium sebagai pusat kegiatan dan vocal point spasial Mall, serta memperkuat kesan arsitektural ruang dalam Mall dengan pencahayaan buatan yang stabil dan terang. Dua teknik arsitektural tersebut dimaksudkan 
untuk mengarahkan fokus perhatian pengunjung ke arah ruang dalam Mall dengan membatasi akses terhadap ruang luar dan memperkuat kualitas ruang dalam.

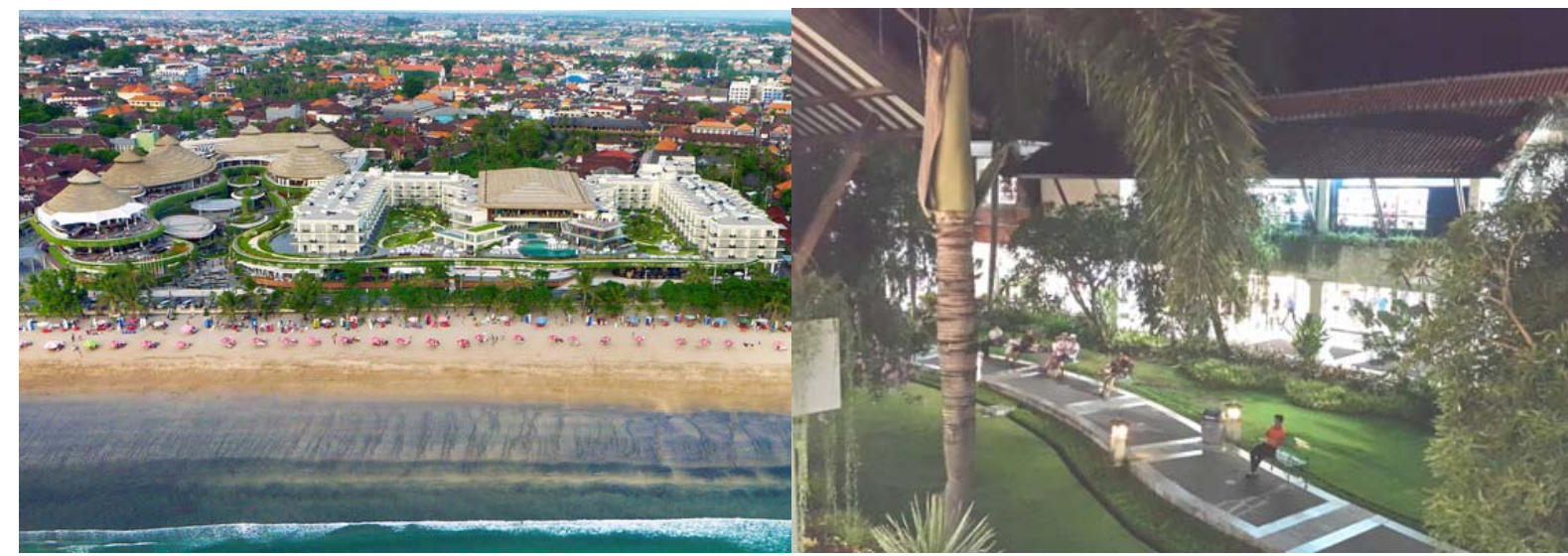

Gambar 2: Lokasi Mall Beachwalk yang berdekatan dengan Pantai Kuta (kiri) dan Ruang terbuka di area tengah Mall Bali Galeria yang difungsikan sebagai ruang sosial (kanan).

Dikaitkan dengan tujuan Mall untuk membentuk gaya hidup konsumtif masyarakat urban, pembatasan akses pengunjung terhadap ruang luar untuk penguatan orientasi ke arah ruang dalam merupakan realisasi dari strategi Mall untuk memperpanjang durasi kegiatan ekonomi di Mall dengan cara memutus hubungan manusia dengan pergerakan alam di ruang luar sebagai penanda waktu, sehingga pengunjung tidak sadar terhadap pergerakan waktu dan akibatnya secara psikologis tidak merasa telah berkegiatan di Mall dalam durasi yang panjang. Seorang pengunjung yang mulai berkegiatan di Mall pada pagi hari, dikarenakan keterputusan dirinya dengan pergerakan alam dan pencahayaan ruang dalam Mall dengan kualitas cahaya yang stabil dan terang, akan merasakan seakan-akan waktu terhenti dan beranggapan hari tetap pagi sebagaimana dirinya datang ke Mall. Kesadaran pengunjung tersebut terhadap pergerakan waktu baru mulai pulih ketika keluar dari Mall dalam kondisi terkejut karena matahari telah condong ke arah Barat yang menandakan hari telah memasuki waktu sore.

Dari keempat ciri khas Mall di atas, salah satunya juga dimiliki pusat perbelanjaan modern yang menerapkan orientasi ke arah dalam didasari logika ekonomi semakin panjang durasi kegiatan ekonomi yang dilakukan di Mall, maka semakin tinggi pula peluang keuntungan ekonomi yang didapatkan pihak pemilik Mall. Sementara itu ciri khas pertama, kedua, dan ketiga hanya dimiliki Mall dan tidak dimiliki pusat perbelanjaan modern dikarenakan antara keduanya menerapkan logika ekonomi yang berbeda. Logika ekonomi Mall yang mendasari ciri khas kedua, ketiga, dan keempat dilandasi dua asumsi. Pertama, intensitas kunjungan yang tinggi akan mendorong terjadinya kegiatan ekonomi yang 
semakin tinggi, sehingga semakin tinggi pula peluang keuntungan ekonomi yang akan didapatkan pihak pemilik Mall.

Berbeda dengan logika ekonomi Mall yang berpatokann pada intensitas kunjungan masyrakat, pusat perbelanjaan modern menerapkan logika ekonomi yang berpatokan pada optimalisasi ruang untuk mendapatkan keuntungan ekonomi yang tinggi dengan prinsip semakin banyak jumlah kios untuk disewakan, maka semakin tinggi pula peluang keuntungan ekonomi yang didapatkan pihak pemilik Mall. Dengan logika tersebut, keberadaan ruang-ruang yang tidak bernilai ekonomi, seperti ruang terbuka yang diperuntukkan untuk fungsi sosial atau bahkan area duduk bagi pengunjung untuk beristirahat di sela kegiatan ekonomi tidak dihadirkan karena tidak memberikan keuntungan ekonomi bagi pemilik Mall. Begitupula dengan bentukan arsitektur yang rekreatif tidak dijadikan panduan dalam perancangan Mall karena menuntut pembiayaan yang lebih tinggi, sehingga pusat perbelanjaan modern cenderung memiliki bentukan arsitektur yang fungsional dengan meniadakan unsur-unsur arsitektural yang sekedar tempelan untuk estetika bangunan. Tetapi dengan logika ekonomi yang mendasari kehadiran Mall, keberadaan ruang terbuka dan bentukan arsitektur yang rekreatif justru dikehendaki untuk meningkatkan intensitas kunjungan masyarakat ke Mall.

Kedua, intensitas kunjungan yang tinggi dimaksudkan untuk membentuk gaya hidup konsumtif masyarakat urban dengan menjadikan kunjungan ke Mall sebagai rangkaian kegiatan rutin sehari-hari. Dalam lingkup lingkungan mikro untuk membentuk gaya hidup konsumtif masyarakat urban, Mall memiliki bentukan arsitektur yang rekreatif, fasilitas pendukung, dan suasana ruang yang menggungah psikologis masyarakat untuk berkunjung dan berkegiatan ke Mall, sebagaimana telah dibahas di atas. Sementara dalam lingkup meso kewilayahan dan makro kota, bentukan arsitektur Mall yang rekreatif dan monumental menegaskannya sebagai penanda atau landmark suatu wilayah dan kota untuk membentuk persepsi publik bahwasanya Mall adalah pusat kota dan merupakan identitas serta wajah kota yang dihuninya. Didasari persepsi publik demikian, masyarakat sebagai penghuni kota secara psikologis akan merasakan kedekatan dirinya dengan Mall yang akan mendorong masyarakat untuk berkunjung dan berkegiatan ke Mall sebagai bagian dari gaya hidupnya selaku masyarakat urban. 
Dibandingkan dengan pasar tradisional maupun pasar modern, seluruh ciri khas Mall tidak dimiliki keduanya. Baik pasar tradisional maupun pasar modern hanya memiliki fasilitas jual-beli sebagai kegiatan utama, sehingga orientasi masyarakat yang berkunjung ke pasar hanya sebatas melangsungkan kegiatan jual-beli untuk mendapatkan barang yang menjadi kebutuhannya sehari-hari. Begitupula dalam penentuan lokasi maupun tata ruangnya, pasar tradisional maupun pasar modern tidak ditujukan untuk membentuk suasana ruang yang mampu menggugah psikologis masyarakat. Dari segi lokasi, pembangunan pasar tradisional dan pasar modern mempertimbangkan kedekatan dengan permukiman masyarakat yang merupakan modal sosial pasar untuk menjamin keberlangsungan kegiatan ekonomi. Dasar penentuan lokasi tersebut membedakan pasar dari pusat perbelanjaan modern dan Mall yang menjadikan kedekatan dengan pusat kota atau pusat ekonomi sebagai pertimbangan menentukan lokasi, sehingga jarak antara pusat perbelanjaan modern dan Mall dari permukiman terbilang jauh yang mengharuskan masyarakat menempuh mobilisasi spasial yang tinggi untuk mengakses ruang. Salah satu dampaknya dalam skala makro kota adalah kemacetan di area sekitar pusat perbelanjaan modern apalagi Mall disebabkan intensitas kunjungan masyarakat yang tinggi untuk bekegiatan di pusat perbelanjaan modern maupun Mall.

Dari aspek perwujudan fisik arsitekturalnya, pasar tradisional sebagai objek arsitektur memiliki bentuk yang sederhana untuk tidak mengatakan apa adanya sebagai konsekuensi dari kemampuan teknik dan ketersediaan bahan bangunan setempat. Sementara pasar modern memiliki kesamaan dengan pusat perbelanjaan modern yang menerapkan bentukan arsitektur fungsional. Sedangkan ditinjau dari orientasi ruangnya, pasar tradisional dan pasar modern selain memiliki orientasi ruang ke dalam untuk keperluan kegiatan jual-beli, juga menjaga keterhubungan dengan ruang luar melalui bentukan bangunan yang terbuka sepenuhnya, terbuka setengah dinding, maupun memiliki bukaan yang cukup dan fungsional untuk memanfaatkan secara optimal pencahayaan dan penghawaan alami, sehingga dari ruang dalam dapat melihat masjid maupun bangunan pemerintahan yang pada umumnya memiliki kedekatan dengan pasar.

Dari pembahasan bagian ini dapat disimpulkan ciri khas Mall dan perbedaannya dengan pusat perbelanjaan modern, pasar modern, dan pasar tradisional, melalui tabel di bawah ini: 
Tabel: Ciri khas Mall dan perbedaannya dengan fungsi ekonomi lainnya

\begin{tabular}{llll}
\hline \multicolumn{1}{c}{ Mall } & Perbelanjaan Modern & \multicolumn{1}{c}{ Pasar Modern } & \multicolumn{1}{c}{ Pasar Tradisional } \\
\hline Bentukan arsitektur & Bentukan arsitektur & Bentukan arsitektur & Bentukan arsitektur yang \\
yang rekreatif & fungsional yang & fungsional yang & memanfaatkan teknik \\
& memanfaatkan teknik & memanfaatkan & membangun dan bahan \\
& membangun dan bahan & teknik membangun & bangunan setempat \\
& modern & dan bahan modern & \\
\hline Dilengkapi dengan & Hanya memiliki fasilitas & Hanya memiliki & Hanya memiliki fasilitas \\
fasilitas pendukung & utama jual-beli & fasilitas utama jual- & utama jual-beli \\
yang bersifat hiburan & & beli & \\
\hline Nuansa ruang yang & Nuansa ruang & Nuansa ruang & Nuansa ruang sederhana \\
mengguggah secara & fungsional untuk & fungsional untuk & \\
psikologis & optimalisasi nilai & optimalisasi nilai & \\
& ekonomi & ekonomi & \\
\hline Orientasi ke dalam & Orientasi ke dalam & Orientasi ke dalam & Orientasi ke dalam dan \\
& & dan ke luar & ke luar \\
\hline
\end{tabular}

Sumber: Analisa pribadi, 2019

\section{Status Kehalalan Mall}

Sebagaimana dilansir www.depokpos.com, penyematan status Halal Mall The Park Sawangan dilatarbelakangi identitas masyarakat Depok yang religius dan didasari kehadiran Lulu Hypermart dari Uni Emirat Arab sebagai salah satu gerai di Mall tersebut yang menjual makanan halal dan beragam jenis bumbu khas Timur Tengah.

"Kehadiran Lulu hypermart di The Park Sawangan akan sangat sesuai dengan karakter masyarakat Kota Depok yang religius. Lulu ini tidak hanya menyediakan segala macam kebutuhan sehari-hari layaknya sebuah hypermart, namun juga berbagai ragam bumbu Timur Tengah hingga makanan jadi halal yang sangat menggugah selera".

Berkaca dari The Park Sawangan dan kasus sejenis, citra Islami sebuah Mall dibentuk melalui status Halal produk-produk yang diperjualbelikan dan keberadaan fasilitas peribadatan bagi umat Islam dalam wujud masjid maupun mushala dengan kapasitas ruang yang memadai dan kualitas ruang yang representatif serta lokasi yang mudah diakses dari area perbelanjaan, seperti di tengah area perbelanjaan Mall, di area depan Mall atau bersebelahan dengan Mall. Pertanyaannya adalah, apakah cukup dengan kedua unsur tersebut -produk dan fasilitas ibadah- suatu Mall layak disematkan status Halal atau Islami? Apakah Mall-mall yang berstatus Halal atau Islami berlandaskan konsep dasar yang bersumberkan dari Islam yang secara fundamental membedakannya dengan Mall-mall lain dari aspek tujuan, orientasi ekonomi, dan ciri khasnya? 


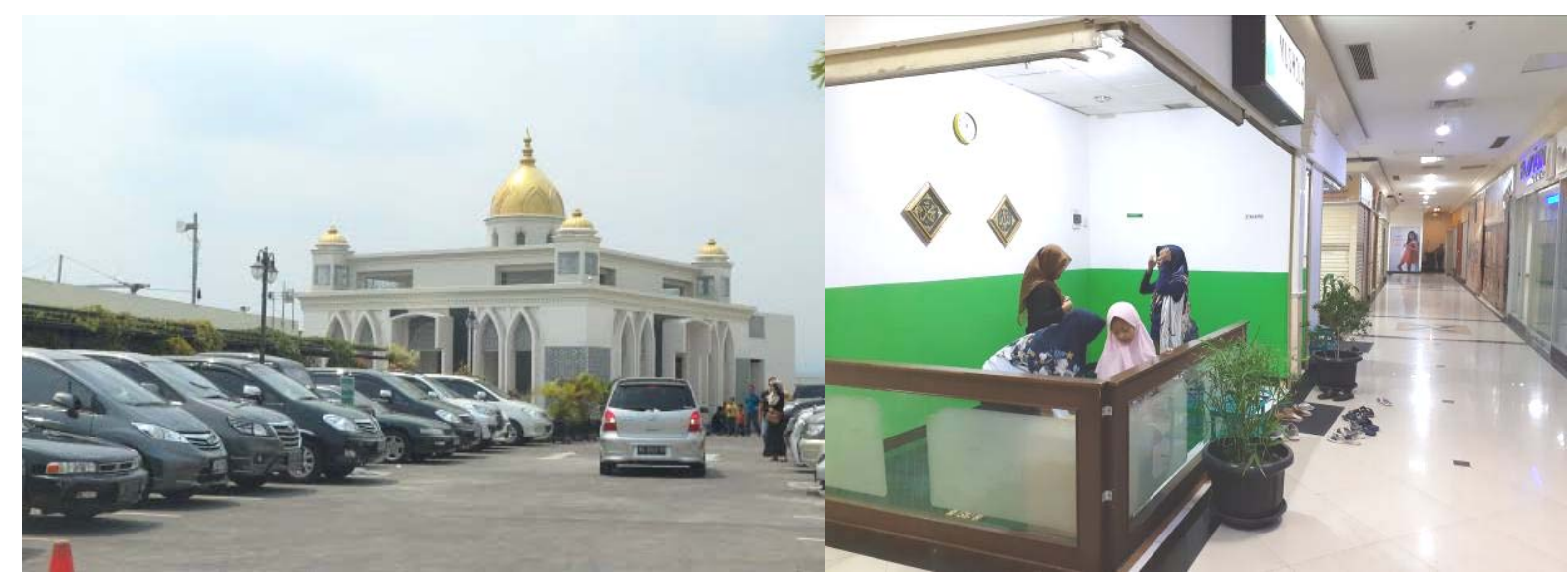

Gambar 3: Masjid di lantai atap Ambarukmo Plaza Mall Yogyakarta (kiri) dan Mushala di tengah ruang ekonomi Grand Mall Solo (kanan).

Tulisan singkat ini tentu saja tidak mampu untuk menjawab deretan pertanyaan di atas secara tuntas dan mendalam karena memang tidak saya tujukan untuk itu. Pada bagian akhir dari tulisan ini saya maksudkan untuk menjelaskan dua gugatan terhadap fenomena Mall Halal atau Islami ditinjau dari kesejarahan yang membentuk ciri khas Mall yang telah dipaparkan pada bagian sebelumnya. Gugatan pertama, penyematan status Halal atau Islami pada suatu Mall bersifat parsial karena menyederhanakan Islam hanya terdiri dari aspek Fikih dan bersifat reduktif dengan menyempitkan Fikih sebatas persoalan status Halal dan Haram suatu persoalan. Penyematan status Halal atau Islami pada suatu Mall secara parsial dan reduktif menjadikan terbatasnya ruang lingkup penilaian hanya pada unsur-unsur yang bersifat fisik, seperti produk yang dijual dan ketersediaan fasilitas peribadatan bagi umat Islam, sedangkan unsur-unsur yang bersifat abstrak tidak dapat dijangkau seperti konsep dasar, tujuan, orientasi ekonomi, dan ciri khas arsitektural yang merupakan derivasi dan realisasi dari ketiga unsur tersebut.

Dengan keterbatasan ruang lingkup penilaian, akan muncul pertanyaan-pertanyaan lain. Apakah penyematan status Halal atau Islami pada suatu Mall memadai jika tujuan kehadirannya untuk membentuk gaya hidup konsumtif masyarakat Muslim urban dengan orientasi ekonomi kapitalistik bagi pemilik Mall untuk meraup keuntungan ekonomi sebesar-besarnya dari umat Islam? Lalu bagaimana jika sebelum pendirian Mall yang disematkan status Halal atau Islami dilakukan penggusuran hunian kalangan ekonomi lemah yang dilakukan oleh pemerintah dan diaktori oleh pemodal besar? Bagaimana pula jika sepanjang operasional Mall yang berstatus Halal atau Islami membutuhkan energi listrik dan sumber air bersih yang terbilang besar di tengah ketidakadilan energi dan ketersediaan air bersih bagi masyarakat kecil? Persoalan-persoalan inilah yang tidak mampu dijangkau dengan pendekatan Islam yang parsial dan reduktif, sehingga kehadiran Mall yang 
menyandang status Halal maupun Islami tidaklah mencerminkan Islam secara menyeluruh karena hanya bagian kecil saja dari tuntutan Islam yang dipenuhi.

Gugatan kedua, penyematan status Halal atau Islami pada Mall tidak berlandaskan pandangan-alam Islam (Islamic worldview) karena dilatarbelakangi Pragmatisme belaka untuk kepentingan ekonomi pemilik Mall yang sama sekali tidak bermuatan spiritualitas Islam, tidak terkecuali The Park Sawangan yang dimiliki oleh NWP Retail dengan Warburg Pincus sebagai pemegang saham terbesar di mana keduanya bukanlah merupakan bagian dari umat Islam, sehingga tidak meyakini kebenaran asas keyakinan Islam yang membentuk cara pandang dan penilaiannya terhadap realitas. Pragmatisme dalam kegiatan ekonomi bertentangan secara diametral dengan Islam karena merupakan etika yang memperbolehkan dilakukannya segala hal untuk mendapatkan keuntungan bagi diri sendiri, sehingga tata nilai Pragmatisme lumrah dianut kalangan pemodal yang berorientasi ekonomi-kapitalistik karena menyediakan ruang dan pembenaran baginya untuk melakukan akumulasi modal tanpa batas dan hambatan, termasuk dengan memanfaatkan sentimen keagamaan masyarakat Muslim urban yang tengah tumbuh subur untuk berkunjung sesering mungkin dan memperpanjang kegiatan ekonomi di Mall.

Pragmatisme yang mendasari penyematan status Halal atau Islami pada Mall terlihat dari penyediaan ruang ibadah untuk umat Islam yang walaupun dihadirkan dengan kualitas arsitektural yang representatif seperti dilengkapi penghawaan buatan dan alas lantai yang nyaman untuk sujud dalam pelaksanaan ibadah shalat, tetapi tidak memenuhi kebutuhan psikologis umat Islam untuk dapat melaksanakan ibadah dengan khusyuk dan tepat waktu disebabkan rembesan suara transaksi jual-beli dari ruang ekonomi yang masuk ke dalam ruang peribadatan dan suara adzan yang tidak dikumandangkan ke dalam ruang ekonomi untuk Mall yang memiliki masjid sebagai pengingat telah masuknya waktu shalat. Kehadiran masjid maupun mushala di Mall yang didasari pragmatisme sekedar berorientasi memenuhi kebutuhan spasial pengunjung Muslim untuk mempanjang durasi kegiatan ekonomi di Mall dengan cara melangsungkan peribadatan shalat di Mall disela kegiatan konsumsi yang sedang dilakukan.

Dua gugatan yang telah saya sampaikan di atas bukan tidak berdasar, karena secara arsitektural ciri khas Mall-mall yang disematkan status Halal atau Islami tidak berbeda dengan Mall selainnya. Pertama, Mall-mall yang disematkan status Halal atau Islami memiliki bentukan arsitektur yang rekretif sebagai daya tarik secara psikologis untuk menarik minat umat Islam berkunjung dan berkegiatan di Mall. Dalam lingkup individual, bentukan arsitektur yang rekreatif merupakan stimulus yang bersifat emosional untuk 
mempengaruhi kondisi kejiwaan umat Islam agar cenderung pada kesenangan dan kenikmatan sebagai daya dorong untuk melakukan kegiatan konsumsi di Mall. Apalagi pada titik ekstrimnya, stimulus emosional yang bermuatan kesenangan dan kenikmatan pada bentukan arsitektur Mall akan mengakibatkan manusia terjebak pada pengalaman visualemosional-konsumtif yang menjadikannya tunduk bagai budak pada segala keinginan hawa nafsu. Kondisi kejiwaan demikian tidak dibenarkan menurut Islam yang memerintahkan dan mendidik umat Islam untuk senantiasa menundukkan dorongan emosional di bawah kendali akal yang diterangi cahaya wahyu.

Dalam lingkup komunal umat Islam yang disebut Ummah, kehadiran Mall dengan bentukan arsitektur yang rekreatif dan monumental untuk membentuk persepsi masyarakat Muslim bahwasanya Mall merupakan penanda, wajah, dan identitas kota, sehingga akan mendekatkan dan mengikat umat Islam dengan Mall secara psikologis, bertentangan dengan Islam maupun kesejarahan Peradaban Islam yang menjadikan masjid sebagai jangkar persepsi bagi masyarakat Muslim untuk membentuk wajah dan identitas suatu wilayah serta mengikat kuat dirinya dengan masjid, sebagaimana dilandasi dan terinspirasi dari Hadits berikut (yang artinya),

"Tempat yang paling dicintai oleh Allah dalam suatu negeri adalah masjidmasjidnya dan tempat yang paling dibenci oleh Allah adalah pasar-pasarnya". (Riwayat Muslim)

Kedua, Mall-mall yang disematkan status Halal atau Islami memiliki orientasi ruang ke dalam dengan memutus hubungan dengan ruang luar, fasilitas pendukung yang bersifat hiburan seperti mengadakan kontes hijab, kontes musik Islami, gym yang terpisah antara pengunjung pria dan wanita, dan suasana ruang berkesan Islami dengan dekorasi ruang yang berciri khas identitas umat Islam dan lagu-lagu nasyid yang diperdengarkan di seluruh pejuru ruang Mall dengan tujuan meningkatkan intensitas kunjungan dan memperpanjang durasi kegiatan ekonomi umat Islam di Mall, sehingga umat Islam larut dalam beragam kegiatan di Mall hingga lupa waktu yang tidak dapat dibenarkan menurut Islam berdasarkan Hadits di atas.

Kebencian Allah terhadap pasar sebagaimana termuat dalam Hadits di atas disebabkan dua hal. Pertama, pasar yang merupakan ruang ekonomi, sebagaimana Mall, identik dengan perilaku individualistik untuk mencari keuntungan materi bagi diri sendiri, seperti mencurangi timbangan yang telah dicela Allah dalam Surah Al-Muthaffifin. Termasuk dalam lingkup persoalan ini adalah merekayasa kondisi psikologis masyarakat 
untuk meningkatkan intensitas kunjungan dan memperpanjang durasi kegiatan di Mall demi tercapainya kepentingan ekonomi pemilik Mall, yang menjadikan masyarakat melakukan kegiatan ekonomi di Mall bukan atas dasar utilitarian untuk memenuhi kebutuhan hidupnya yang bersifat mendasar, tetapi untuk melepaskan hasrat konsumtifnya. Kedua, terkait dengan yang pertama, kebencian Allah terhadap pasar dikarenakan umat Islam larut dalam kegiatan di ruang ekonomi hingga menunda bahwa meninggalkan kegiatan peribadatan di masjid. Argumentasi inilah yang menegaskan walaupun disematkan status Halal atau Islami, Mall pada hakikatnya merupakan ruang yang dibenci Allah karena tidak berbeda secara fundamental dengan Mall-mall pada umumnya.

Dapat disimpulkan, penyematan status Halal atau Islami pada suatu Mall tidaklah tepat karena ditinjau dari (1) unsur gagasan untuk membentuk gaya hidup konsumtif masyarakat urban; (2) unsur perilaku mengunjungi Mall dengan intensitas yang tinggi dan berkegiatan di Mall dengan durasi yang panjang untuk memenuhi hasrat konsumtif; dan (3) unsur artefak arsitektural yang rekreatif sebagai daya tarik yang bersifat emosional untuk mempengaruhi kondisi psikologis masyarakat agar berkunjung dan berkegiatan di dalam Mall, bertentangan dengan Islam. Sementara itu penyediaan produk-produk Halal, fasilitas ruang ibadah, serta fasilitas pendukung dan suasana ruang yang identik dengan identitas Islam dan umat Islam dilandasi tata nilai Pragmatisme untuk kepentingan akumulasi kapital pemilik Mall. Dengan demikian, penyematan istilah Halal atau Islami pada Mall tidaklah tepat karena tidak melingkupi seluruh unsur Mall sebagai ruang kegiatan manusia, dan tidaklah pantas karena akan membingungkan dan memperdaya kalangan masyarakat awam. Selain itu penyematan Halal atau Islami pada ruang perekonomian, termasuk Mall, yang dilakukan sekenanya saja sekedar untuk kepentingan ekonomi individualistik, patut dinyatakan sebagai perbuatan menista Islam karena telah mempergunakan simbol-simbol dan konsep-konsep khas Islam untuk perbuatan, kepentingan, dan tujuan yang bertentangan dengan Islam.

Allahu a'lam bishawab.

Bertempat di Kartasura pada Dzulqa' dah 1440 Hij rah Nabi 